\title{
PERAN PAGUYUBAN DALAM PEMBANGUNAN KAWASAN DESA
}

\author{
The Role of Paguyuban in Rural Development
}

\author{
Zessy Ardinal Barlan*) Lala M. Kolopaking dan Satyawan Sunito \\ Departemen Sains Komunikasi dan Pengembangan Masyarakat, Fakultas Ekologi Manusia, IPB \\ *)Email : zessy_ab@yahoo.com
}

Tanggal Diterima/Tanggal Disetujui: 23 April 2014

\begin{abstract}
Balikpapan is famous for its ethnic diversity. The consequences of such a diverse community is certainly emerging a lot of paguyuban (ethnic community). Each paguyuban (ethnic community) has norms and values that influencing behavior and decision making of individual. Therefore it is important to analyze how the influence of the paguyuban (ethnic community) encouraging the formation of pillarization society and its impact on rural development. This study used qualitative and quantitative methods. Thus this research is descriptive and exploratory research. Basically the presence of paguyuban (ethnic community) have been strengthening community identity and encouraging the form of society pillarization. Furthermore the paguyuban (ethnic community) encourage the development of rural areas through elites who are members of the association for the benefit of its ethnic and became as a network security for poor people who cannot receive a direct benefit from the development of the region.
\end{abstract}

Keywords: Ethnic Community, Pillarization Society, Rural Development

\section{ABSTRAK}

Balikpapan merupakan daerah dengan masyarakat yang multietnik. Konsekuensi dari masyarakat beragam tersebut tentunya berdampak pada cukup banyak muculnya paguyuban etnis. Masing-masing paguyuban etnis ini memiliki norma dan nilai yang mempengaruhi individu dalam berprilaku dan mengambil keputusan. Oleh sebab itu penting untuk melihat bagaimana pengaruh paguyuban etnis dalam mendorong terbentuknya pilarisasi masyarakat dan dampaknya pada pembangunan desa. Penelitian ini menggunakan metode kualitatif dan kuantitatif. Dengan demikian penelitian ini merupakan penelitian dekriptif dan eksplorasi. Kehadiran paguyuban pada dasarnya memperkuat identitas etnik dan mendorong terjadinya pilarisasi masyarakat. Selain itu paguyuban etnis juga mendorong pembangunan kawasan desa melalui elit-elit yang tergabung di paguyuban tersebut untuk kepentingan etnisnya dan menjadi sarana pengaman bagi masyarakat miskin yang tidak bisa menerima manfaat langsung dari pembangunan kawasan tersebut.

Keywords: Ethnic Community, Pillarization Society, Rural Development

\section{PENDAHULUAN}

Indonesia terkenal dengan keberagaman etnis yang dimilikinya. Banyaknya etnisitas di Indonesia memberikan warna tersendiri bagi kehidupan bangsa Indonesia. Salah satunya berdampak pada munculnya organisasi-organisasi dengan landasan etnisitas atau terkadang dikenal dengan sebutan paguyuban. Balikpapan merupakan daerah dengan masyarakat multietnis yang pada umumnya bukan penduduk asli Balikpapan, melainkan pendatang. Tribun Kaltim edisi 30 September 2012 menyebutkan bahwa terdapat 104 paguyuban etnis di Balikpapan. Secara tidak langsung fenomena ini menggambarkan kondisi keberagaman etnis yang ada di Balikpapan. Masingmasing etnis maupun kelompok-kelompok etnis tersebut memiliki norma, relasi maupun jaringan kekerabatan satu dengan lainnya, khususnya untuk kepentingan ekonomi dan politiknya. Lubis (2005) menegaskan bahwa satu kelompok etnik memiliki suatu identitas khas yang berbeda dengan kelompok etnik lain, yang dengan mudah terlihat dari cara mereka mengekspresikan atau mengartikulasikan kebudayaannya, termasuk dalam hal bagaimana mereka mengkonsepsikan dan menata pengelolaan dan penguasaan terhadap sumberdaya (alam, ekonomi, dan politik). Hal ini menekankan bahwa adanya pola-pola relasi yang dibangun dan digunakan didalam kelompok etnik untuk mengelola sumberdaya khususnya dalam sektor ekonomi dan politik. Pola-pola relasi ini tentunya tidak terlepas dari jaringan kekerabatan yang dibangun oleh masing-masing kelompok etnik. Fenomena ini dapat memiliki dampak pada semakin kuatnya identita etnik dari masing-masing etnis di Balikpapan.

Kesejahteraan masyarakat desa merupakan salah satu faktor penting yang dipertimbangkan dalam pembangunan kawasan desa, namun pada kenyataannya pembangunan kawasan di pedesaan masih erat kaitannya dengan kondisi 
sosial ekonomi politik kota. Pembangunan kawasan desa pada dasarnya tidak dapat terlepas dari fenomena gejala menguatnya identitas etnik dan peran paguyuban di Balikpapan, maka dari itu, penting untuk melihat bagaimana pengaruh paguyuban dalam penguatan identitas etnik dan dampaknya pada pembangunan desa. Hal ini penting dilihat dalam kaitannya untuk menganalisis lebih jauh dampak pembangunan tersebut terhadap perekonomian masyarakat desa khususnya masyarakat miskin. Penelitian ini akan mencoba melihat bagaimana peran paguyuban dalam pembangunan kawasan pedesaan dan juga ingin mencoba melihat peran dan dampaknya pada perekonomian masyarakat pedesaan, khususnya masyarakat yang terkategori miskin.

\section{Tujuan Penelitian}

Penelitian ini pada dasarnya bertujuan untuk menjelaskan peran paguyuban dalam pembangunan kawasan desa. Adapun dalam mencapai tujuan penelitian tersebut, diperlukan untuk menjelaskan dan menganalisis beberapa hal diantaranya sebagai berikut:

1. Menjelaskan bagaimana peran paguyuban dalam mendorong identitas etnik di Balikpapan.

2. Menjelaskan bagaimana peran paguyuban dalam pembangunan kawasan desa.

\section{TINJAUAN PUSTAKA}

\section{Kelompok Etnik dan Identitas Etnik}

Lubis (2005) mengatakan bahwa satu kelompok etnik memiliki suatu identitas khas yang berbeda dengan kelompok etnik lain, yang dengan mudah terlihat dari cara mereka mengekspresikan atau mengartikulasikan kebudayaannya, termasuk dalam hal bagaimana mereka mengkonsepsikan dan menata pengelolaan dan penguasaan terhadap sumberdaya (alam, ekonomi, dan politik). Adapun Lawang (2005) dalam bukunya menyebutkan bahwa sukubangsa menunjuk pada kolektifitas sosial yang memiliki struktur sosial, kebudayaan, bahasa, agama tradisional yang sama yang muncul dan berkembang dari salah satu daerah tertentu di Indonesia. Dengan ciri-ciri tersebut seseorang mengidentifikasikan diri sendiri dan didefenisikan orang lain termasuk ke dalam suku bangsa itu. hasilnya adalah identitas sukubangsa (ethnic identity). Sedangkan identitas etnik menurut Esman (1994) adalah "the set of meanings that individuals impute to their membership in an ethnic community, including those attributes that bind them to that collectivity and that distinguish it from others in their relevant environment".

\section{Kerangka Pemikiran}

Etnisitas yang beragam di Balikpapan akhirnya mendorong masing-masing etnisitas tersebut membentuk organisasiorganisasi yang disebut Paguyuban. Seperti yang telah dijelaskan Lubis (2005) bahwa satu kelompok etnik memiliki suatu identitas khas yang berbeda dengan kelompok etnik lain, yang dengan mudah terlihat dari cara mereka mengekspresikan atau mengartikulasikan kebudayaannya, termasuk dalam hal bagaimana mereka mengkonsepsikan dan menata pengelolaan dan penguasaan terhadap sumberdaya (alam, ekonomi, dan politik). Berdasarkan hal tersebut maka pada dasarnya terdapat relasi antara aktor terhadap kelompok etnisnya, diamana relasi ini dipengaruhi oleh nilai maupun norma yang yang dikonsepsikan dan dibuat berdasarkan kesepakatan bersama.

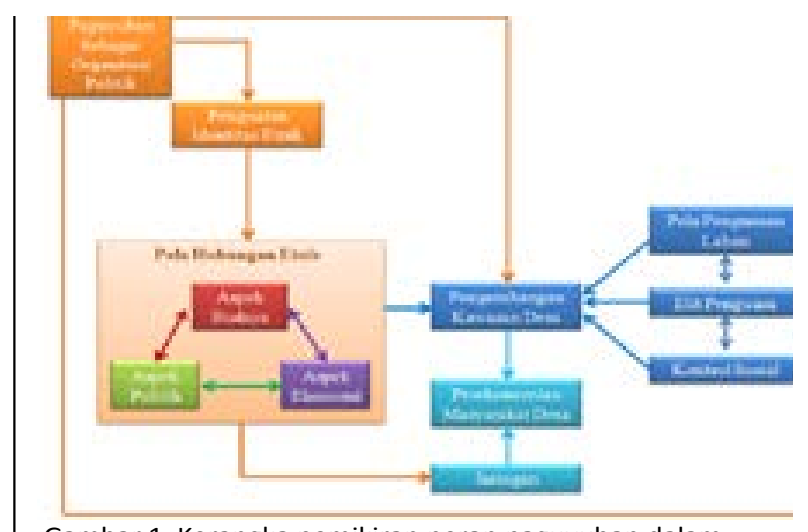

Gambar 1 Kerangka pemikiran peran paguyuban dalam nengembangan kawasan desa

Berdasarkan hal ini semakin kuatnya paguyuban maka pada dasarnya juga akan semakin memperkuat identitas etnik yang dimiliki masyarakat. Identitas etnik yang semakin kuat tentunya membuat nilai-nilai menjadi landasan dalam aktor berprilaku. Hal ini tentunya mempengaruhi pola-pola hubungan yang terjadi diantara masyarakat khususnya pada aspek budaya, ekonomi, dan politik. Pola-pola hubungan ini pada akhirnya juga mempengaruhi relasi antar aktor atau elit yang menguasai sumberdaya dengan masyarakat dimana Barth menegaskan bahwa banyak kegiatan politik dari sang innovator melibatkan kodifikasi adat, misalnya pemilihan tanda untuk identitas dan penentuan nilai budaya, serta penekanan atau penolakan bentuk budaya lain. Hal ini dimaksudkan untuk membantu sang inovator untuk menggerakkan pendukung dan membantunya dalam strategi menghadapi kelompok lain. Dampaknya yang berbeda bagi anggota kelompoknya sendiri maupun bagi kelompok lain adalah penting, yaitu merupakan sumberdaya dan distribusi pengaruh bagi kelompoknya.

Pola-pola hubungan tersebut pada dasarnya akan mempengaruhi aktor maupun elit yang berkuasa, hal ini dapat mempengaruhi aspek ekonomi dan politik khususnya pengembangan kawasan desa. Adapun pengaruh dari pola hubungan terhadap pengembangan kawasan desa ini dapat terlihat dari tiga hal yaitu pola penguasaan lahan, elit penguasa dan kontrol sosial di desa tersebut dimana ketiga hal ini juga saling mempengaruhi satu dengan lainnya dan dipengaruhi oleh peran paguyuban didalamnya Selain dalam pengambangan kawasan desa, pola hubungan juga mempengaruhi perluasan jaringan. Seperti kita ketahui bahwa dengan bergabung pada organisasi-organisasi dan dengan memanfaatkan pola hubungan tertentu maka akan memperluas jaringan yang dimiliki oleh individu. Perluasan jaringan ini tentunya berdampak pada lebih terbukanya akses mencari pekerjaan. Dewasa ini dalam mencari pekerjaan tidak hanya dibutuhkan pendidikan yang tinggi melainkan juga jaringan karena terdapat beberapa lowongan pekerjaan yang tidak diumumkan melainkan hanya diberitahukan melalui kerabat saja. Maka dari itu adanya pengembangan kawasan desa dan perluasan jaringan masyarakat akan mempengaruhi kondisi perekonomian masyarakat desa. Adapun kerangka pemikiran dari penelitian ini dapat dilihat pada gambar 1 . 


\section{METODOLOGI}

Penelitian ini menggunakan metode kualitatif. Dengan demikian penelitian ini merupakan penelitian dekriptif dan eksplorasi. Penelitian ini akan dilakukan dengan wawancara mendalam kepada informan yang terlibat dalam kelompok etnis, pemerintah, aktor atau elit. Adapun instrumen wawancara mendalam dengan menggunakan panduan pertanyaan tertulis. Jenis data yang akan digunakan dalam penelitian ini ialah data sekunder (studi literatur yang dilakukan untuk mendapatkan data dan informasi yang relevan mengenai penelitian ini) dan data primer (pengamatan langsung di lokasi penelitian dimana dilakukan wawancara mendalam kepada informan yang mengacu kepada panduan pertanyaan). Penelitian mengenai peran paguyuban dalam pembangunan kawasan desa ini dilaksanakan di salah satu desa di sekitar kota Balikpapan Kalimantan Timur yaitu Karang Joang.

\section{PEMBAHASAN}

Tabel 1. Peran Paguyuban dalam Penguatan Identitas Etnik dan Dampaknya Pada Bentuk Masyarakat Majemuk di Balikpapan

\begin{tabular}{|c|c|c|c|c|c|}
\hline Suku & $\begin{array}{l}\text { Nilai } \mathrm{Bu}- \\
\text { daya }\end{array}$ & $\begin{array}{l}\text { Latar Be- } \\
\text { l a k a n g } \\
\text { P e n g e m- } \\
\text { bangan Jar- } \\
\text { ingan }\end{array}$ & $\underset{\text { Ekonomi }}{\text { Dampak }}$ & $\begin{array}{l}\text { Strategi } \\
\text { Politik }\end{array}$ & $\begin{array}{l}\text { M a t a } \\
\text { Penca- } \\
\text { harian } \\
\text { Domi- } \\
\text { nan }\end{array}$ \\
\hline Jawa & $\begin{array}{l}\text { W e w e h } \\
\text { tanpa ke- } \\
\text { la } \mathrm{n} \text { g a n } \\
\text { yang be- } \\
\text { rarti mem- } \\
\text { beri tanpa } \\
\text { harus ke- } \\
\text { hilangan } \\
\text { sesuatu }\end{array}$ & $\begin{array}{l}\text { Sesama an- } \\
\text { ggota harus } \\
\text { saling to- } \\
\text { long meno- } \\
\text { long }\end{array}$ & $\begin{array}{l}\text { Manda- } \\
\text { hulukan } \\
\text { kerabat } \\
\text { jika ada } \\
\text { lowongan } \\
\text { pekerjaan }\end{array}$ & $\begin{array}{l}\mathrm{K} \text { a m - } \\
\text { p a n y e } \\
\text { diwaktu } \\
\text { berkum- } \\
\text { pul ang- } \\
\text { gota pa- } \\
\text { guy uban } \\
\text { dan me- } \\
\text { wakili pa- } \\
\text { guyuban } \\
\text { pada aca- } \\
\text { ra-acara } \\
\text { besar }\end{array}$ & $\begin{array}{l}\text { B e r d - } \\
\text { a g a n g } \\
\text { d a n } \\
\text { U s a h a } \\
\text { Kuliner }\end{array}$ \\
\hline Bugis & $\begin{array}{l}\text { siri' } \\
\text { passe, dan }\end{array}$ & $\begin{array}{l}\text { Pola pe- } \\
\text { manfaatan } \\
\text { jar i g gan } \\
\text { tetap terjadi } \\
\text { walaupun } \\
\text { k eb erag- } \\
\text { aman tinggi }\end{array}$ & $\begin{array}{l}\mathrm{P} \text { e j a - } \\
\text { bat ikut } \\
\text { m e m - } \\
\text { b a n t u } \\
\text { mencari } \\
\text { pekerjaan }\end{array}$ & $\begin{array}{l}\text { Memban- } \\
\text { tu kegia- } \\
\text { tan pa- } \\
\text { guy uban } \\
\text { dan mem- } \\
\text { p er mu }- \\
\text { dah akses } \\
\text { memperoleh } \\
\text { pekerjaan }\end{array}$ & $\begin{array}{l}\text { B e r d - } \\
\text { a g a n g } \\
\text { dan Ne- } \\
\text { layan }\end{array}$ \\
\hline $\begin{array}{l}\text { Ban - } \\
\text { jar }\end{array}$ & $\begin{array}{l}\text { Asal satu } \\
\text { keturunan } \\
\text { harus sal- } \\
\text { ing mem- } \\
\text { bantu }\end{array}$ & $\begin{array}{l}\text { Dimanapun } \\
\text { berada tetap } \\
\text { m e n g.gu- } \\
\text { nakan iden- } \\
\text { titas etnik } \\
\text { dan saling } \\
\text { tolong-me- } \\
\text { nolong }\end{array}$ & $\begin{array}{l}\text { Menda- } \\
\text { hulukan } \\
\text { saudara } \\
\text { da a a m } \\
\text { m e m - } \\
\text { berikan } \\
\text { pekerjaan } \\
\text { tet a p i } \\
\text { tetap me- } \\
\text { lihat ke- } \\
\text { mampuan }\end{array}$ & $\begin{array}{l}\text { K a m pa- } \\
\text { nye ke } \\
\text { in ternal } \\
\text { (ses a ma } \\
\text { orang ba- } \\
\text { jar) ter- } \\
\text { hebih da- } \\
\text { hulu baru } \\
\text { ya mas a k t } \\
\text { luar }\end{array}$ & $\begin{array}{l}\text { B erda- } \\
\text { gang ba- } \\
\text { rang-ba- } \\
\mathrm{r} \text { a n g } \\
\mathrm{t} \text { r a - } \\
\text { disional }\end{array}$ \\
\hline Batak & $\begin{array}{l}\text { Da a lih a n } \\
\text { Na Tolu }\end{array}$ & $\begin{array}{l}\text { Saling to- } \\
\text { long meno- } \\
\text { long dalam } \\
\text { hal kese- } \\
\text { jaht eraan } \\
\text { dan peker- } \\
\text { jaan serta } \\
\text { a d a n y a } \\
\text { penggunaan } \\
\text { marga }\end{array}$ & $\begin{array}{l}\text { Memban- } \\
\text { tu kerabat } \\
\text { dari tidak } \\
\text { memiliki } \\
\text { apa-apa } \\
\text { menjadi } \\
\text { lebih se- } \\
\text { jahtera } \\
\text { denga n } \\
\text { kondisi } \\
\text { ekonomi } \\
\text { yang sta- } \\
\text { bil }\end{array}$ & $\begin{array}{l}\text { M e r e - } \\
\text { ka yang } \\
\text { p e r a h } \\
\text { menjabat } \\
\text { s ebaga } \\
\text { ketua pa- } \\
\text { guyuban, } \\
\text { selanjut- } \\
\text { nya men- } \\
\text { cal o n k- } \\
\text { an diri } \\
\text { menja d } \\
\text { ang go ta } \\
\text { D P R D } \\
\text { serta ber- } \\
\text { kampanya } \\
\text { pada sara- } \\
\text { na-sarana } \\
\text { berk um- } \\
\text { pul ang- } \\
\text { gota pa- } \\
\text { guyuban }\end{array}$ & $\begin{array}{l}\text { P e g a }- \\
\text { wai di } \\
\text { pemer- } \\
\text { intahan } \\
\text { maupun } \\
\text { swasta }\end{array}$ \\
\hline
\end{tabular}

Mengacu pada definisi identitas etnik menurut Esman
(1994) yang telah disebutkan sebelumnya, identitas etnik berkembang di Balikpapan terlihat dari berkembangnya paguyuban di Balikpapan. Masyarakat Balikpapan secara sekilas terlihat bahwa masyarakatnya tidak menampakkan identitas etnik yang mereka miliki, namun pada kenyataannya, paguyuban-paguyuban yang terus berkembang di Balikpapan tentunya tidak terlepas dari pengakuan kesediaan individu tergabung dalam suatu paguyuban. Hal ini secara tidak langsung juga menunjukkan pengakuan identitas etnik yang mereka miliki. Muncul dan berkembangnya paguyuban yang berkembang di Balikpapan seperti yang telah dipaparkan sebelumnya membuat masyarakat sesama etnis semakin kuat interaksinya, hal ini dapat lebih jelas dilihat pada tabel 1 .

Penggunaan atribut etnis juga kerap terlihat pada beberapa etnis, seperti penggunaan gelar Andi dan bahasa Bugis pada etnis Bugis, dan penggunaan marga pada etnis Batak. Pada etnis Jawa atribut yang berkembang lebih jelas pada penggunaan bahasa. Bahasa Jawa merupakan bahasa yang selalu menjadi bahasa yang cepat berkembang luas di daerah lain. Hal ini karena adanya penggunaan secara konsisten yang dilakukan oleh penduduk etnis Jawa setiap mereka berinteraksi dimanapun mereka berada. Sama halnya dengan bahasa Banjar. Bahasa Banjar merupakan bahasa yang hampir digunakan secara menyeluruh di Balikpapan, bahkan beberapa remaja ada yang menyebut bahasa Banjar sebagai bahasa "bubuhan" Balikpapan. Melihat fenomena ini, maka dapat disimpulkan identitas etnik di Balikpapan pada dasarnya mengalami pertumbuhan dan semakin menguat (tabel 2).

Tabel 2. Penggunaan Atribut Etnis pada Etnis Bugis, Banjar, Jawa, dan Batak.

\begin{tabular}{ll}
\hline Etnis & Penggunaan Atribut Etnis \\
\hline Bugis & $\begin{array}{l}\text { Penggunaan gelar Andi dan bahasa Bugis da- } \\
\text { lam keseharian }\end{array}$ \\
Banjar & $\begin{array}{l}\text { Penggunaan bahasa Banjar dalam keseharian } \\
\text { Jawa }\end{array}$ \\
Batak & $\begin{array}{l}\text { Penggunaan bahasa Jawa dalam keseharian } \\
\text { keseharian marga dan bahasa Batak dalam }\end{array}$ \\
Sumber: Data Primer(Diolah)
\end{tabular}

Fenomena inilah yang kemudian disinyalir sebagai pendorong adanya gejala pilarisasi masyarakat Balikpapan. Fenomena pilarisasi pada awalnya dapat terlihat pada masyarakat Belanda. Toleransi sebagai identitas nasional Belanda mencuat ketika pemerintah Belanda mengesahkan konsep verzuiling pada abad $19 \mathrm{M}$. Secara harfiah istilah verzuiling dapat diterjemahkan sebagai, "pilarisasie berasal dari kata dasar zuilen yang berarti pilar. Verzuiling adalah pembentukan kelompok-kelompok sub-kultur, masing-masing kelompok terpisah dari yang lain, tiap kelompok diwakili partai politiknya masing-masing, dan tiap kelompok memiliki karakteristik institusi religiusnya sendiri (Mcleod 1997 dalam Nadzir 2011). Konsep politikreligius ini muncul dari tarik menarik kepentingan di Belanda pada pertengahan abad $19 \mathrm{M}$. Konsep ini juga dapat dilihat sebagai puncak dari eksperimen Belanda terhadap multikulturalisme plural, yang memberikan ruang sebesar-besarnya bagi kebebasan ekspresi budaya tiap kelompok. 
Jika melihat pemaparan sebelumnya, gejala ini juga timbul di Balikpapan. Walaupun gejala ini tidak timbul secara terang-terangan dikarenakan kebijakan pemerintah, tetapi secara tidak langsung pemerintah yang memberikan ruang sebebas-bebasnya bagi etnisitas untuk membentuk organisasi maupun kegiatan-kegiatan lain berbasiskan etnis secara tidak langsung berdampak pada munculnya fenomena pilarisasi masyarakat. Sebagai contoh masingmasing etnis tentunya memiliki organisasi sendiri dan sistem kelembagaan sendiri diantara mereka. Bahkan masih ada acara-acara yang bersifat upacara adat (walaupun telah mengalami penyesuaian) tetap masih dilakukan. Kemudian, adanya radio-radio khusus bagi etnis tertentu yang memang menggunakan bahasa daerah, salah satunya adalah adanya radio Jawa banyumas yang menyiarkan siaran dengan menggunakan bahasa Jawa, lagu-lagu daerah dan perkembangan daerah asal dan masyarakat etnis Jawa di Balikpapan.

Tentunya terdapat perbedaan antara fenomena pilarisasi masyarat di Belanda dengan Indonesia khususnya Balikpapan. Pada tahun 1960, pilarisasi di Belanda mulai memudar dikarenakan banyak anggota pilar-pilar tersebut yang mulai tidak loyal pada pilarnya dan masyarakatnya mulai lintas pilar. Selain itu yang pada awalnya pilarpilar tersebut memenuhi kebutuhannya sendiri, kini mulai saling menyediakan kebutuhan untuk pilar lain. Hal ini menyebabkan pilar-pilar tersebut mulai rapuh dan memunculkan gerakan-gerakan aksi baru. Fenomena ini berbeda dengan yang terjadi di Balikpapan. Masyarakat Balikpapan pada dasarnya juga tetap menikah antar etnis, namun keturunannya berhak menentukan etnis mana yang akan mereka akui dan paguyuban mana yang akan mereka ikuti. Selain itu adanya spesialisasi pekerjaan dominan yang dikuasai oleh masing-masing etnis membuat terkadang masing-masing etnis juga saling menyediakan kebutuhan etnis lain. Hal ini justru memperkuat posisi masing-masing etnis maupun paguyuban dan semakin memperkuat pilarisasi tersebut. Adapun Paguyuban pada dasarnya juga merupakan wujud nyata dan pengakuan dari pilarisasi itu sendiri.

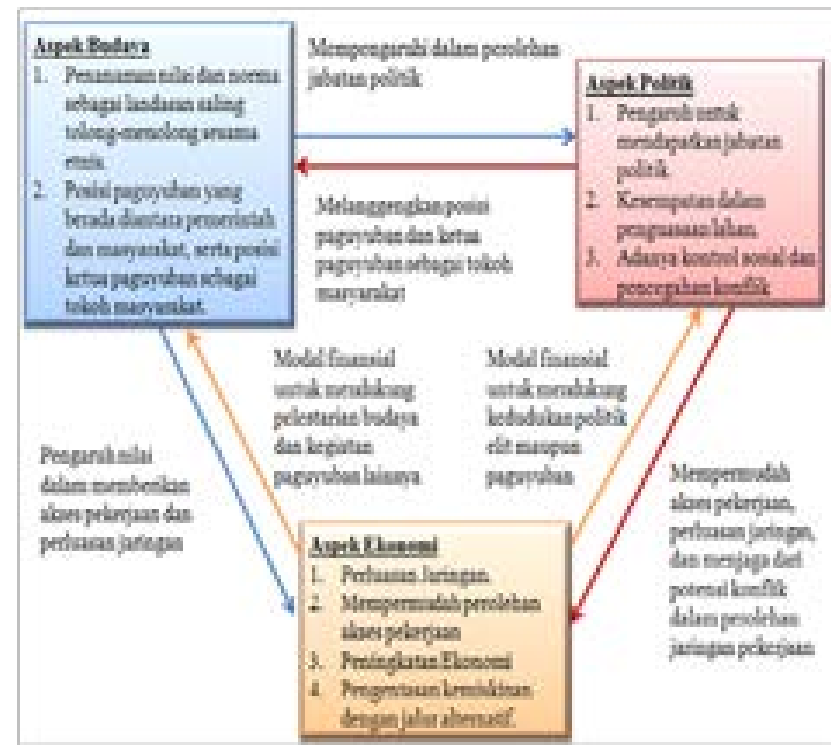

Gambar 2 Pola hubungan etnis pada aspek budaya, politik, dan ekonomi

Pilarisasi masyarakat berdasarkan etnis ini tentunya berperan dalam mempengaruhi aktor dalam berprilaku baik pada identitas budaya serta pengembangan jaringan kekuatan politik dan jaringan kekuatan ekonomi. Pilarisasi yang wujudkan dalam peran-peran paguyuban pada ketiga hal tersebut melahirkan pola hubungan yang saling terkait dimana pola hubungan ini pada dasarnya dilakukan untuk mempekuat posisi masing-masing pilar. Hal ini dapat dilihat pada Gambar 2.

\section{Peran Paguyuban dalam Pembangunan Kawasan Desa}

Seperti yang telah dijelaskan sebelumnya bahwa bagaimana munculnya paguyuban pada dasarnya mendorong tumbuhnya pilarisasi masyarakat di Balikpapan. Tentunya hal ini memiliki implikasi yang erat terhadap pembangunan kawasan desa itu sendiri. Pembangunan kawasan desa tentunya tidak terlepas dalam fenomena politik, siapa yang diuntungkan, dan bagaimana kestabilan desa tersebut dari timbulnya konflik. Maka dari itu, akan dibahas satu persatu mengenai elemen yang terkait dengan pembangunan kawasan pada desa Karang Joang di Balikpapan yaitu pola penguasaan lahan, elit yang berkuasa, dan kontrol sosial.

\section{Peran paguyuban dalam penguasaan lahan}

Pembangunan kawasan Karang Joang tentunya tidak terlepas dari bagaimana pola penguasaan lahan di Karang Joang sendiri. Balikpapan pada awalnya merupakan daerah yang nyaris tidak berpenghuni dibawah kesultanan Kutai. Pada awalnya Balikpapan hanya perkampungan nelayan kecil yang banyak dihuni etnis Bugis. Namun informan penelitian ini (ZA) juga menyebutkan bahwa etnis Bugis pertama kali datang ke Balikpapan biasanya langsung menguasai daerah pesisir dan berprofesi sebagai nelayan. Namun pada migrasi berikutnya dan seterusnya, etnis bugis yang tiba di Balikpapan tidak hanya tinggal di daerah pesisir dan menjadi nelayan, tetapi mereka mulai menggarap lahan, hal ini dikenal dengan kegiatan "merintis". Terdapat dua etnis dominan yang menggarap lahan di Balikpapan yaitu etnis Bugis dan Buton. Kedua etnis ini datang dan tinggal secara berkelompok. Pada saat mereka tiba, belum ada aturan yang jelas mengenai kepemilikan lahan di Balikpapan, sehingga mereka membuka dan menggarap lahan dan menentukan sendiri batas-batas kepemilikan lahan mereka. Pada masa ini paguyuban masih berupa kelompok-kelompok kecil yang berperan untuk membantu dan memfasilitasi mereka yang baru datang dan memulai kegiatan "merintis" ini. Bantuan yang diberikan lebih berupa jaringan dan pertukaran informasi serta saling tolong menolong baik secara kesempatan memperoleh akses dalam usaha ini maupun ekonomi.

Seiring berkembangnya kota Balikpapan yang pada akhirnya menjadi kotamadya berdampak pada diperbaikinya sistem administrasi kepemilikan lahan di Balikpapan. Penduduk etnis bugis yang telah menggarap lahan dan telah menentukan batas-batas kepemilikan lahannya, diminta untuk melengkapi persyaratan administrasi agar mendapatkan sertifikat hak milik yang sah terhadap lahan tersebut. Sertifikasi tersebut dilakukan secara berkelompok dimana melalui-kelompok-kelompok tersebut terjadi sosialisasi informasi dan kesepakatan bersama terkait sertifikasi lahan tersebut. Selain adanya sertifikasi lahan, kota Balikpapan juga menjadi tujuan para transmigran yang di datangkan dari Jawa dengan tujuan untuk membuka lahan.

Fenomena ini juga terjadi di Karang Joang. Menurut aparat 
setempat bahwa banyak lahan di Karang Joang selain yang telah di garap oleh etnis Bugis dan Buton juga diberikan bagi penduduk etnis Jawa sebagai lahan dari program transmigrasi. Selebihnya adalah berupa hutan lindung dimana hutan lindung ini dulunya juga dihuni oleh etnis Banjar. Terkait dengan kepemilkan sertifikasi lahan, orang Bugis mendapatkan sertifikasi atas lahannya begitu pula orang Jawa dengan program transmigrasi, namun etnis Banjar yang telah lama mendiami lahan tersebut harus dikeluarkan dan diberikan tempat tersendiri oleh pemerintah dikarenakan lahan yang mereka huni kini termasuk hutan lindung. Hal ini sesuai dengan pernyataan aparat setempat yang menyebutkan bahwa pada salah satu RT di Karang Joang di dominasi oleh penduduk miskin beretnis Banjar, mereka dulunya tinggal dalam kawasan hutan lindung yang kemudian dikeluarkan oleh pemerintah, namun mereka tentunya tidak lagi memiliki lahan selain lahan seadanya untuk menanam kebutuhan keluarga disekitar rumah mereka.

Sejak Balikpapan menjadi kotamadya maka tentunya Balikpapan memiliki rencana pembangunan, pengembangan ekonomi, dan tata ruang dalam kaitannya dengan pemanfaatan lahan. Mereka yang dapat mengakses rencana pemanfaatan lahan yang akan dilakukan pemerintah cenderung akan membeli lahan dari orang-orang Bugis dan Buton yang pada awalnya menggarap lahan ditempattempat yang diketahui akan terkena pembangunan ekonomi. Hal ini seperti informasi yang didapatkan oleh peneliti bahwa tanah-tanah yang tadinya dimiliki penggarap dibeli oleh para pejabat yang didominasi oleh etnis Jawa. Hal ini dikarenakan para pejabat negara masih sering didatangkan dari pusat. Informasi dari para pejabat Jawa yang dapat mengakses rencana pembangunan dan tata ruang kota disebarkan dalam paguyuban maupun kelompok-kelompok kecil etnis Jawa kepada para anggotanya, mengingat saat itu kepemilikan lahan menjadi penting bagi etnis Jawa yang merupakan pendatang dan tidak memiliki asset tetap di Balikpapan.

Pejabat atau para elit politik Jawa membeli lahan dari para orang Bugis dengan harga murah. Kondisi ini tidak menuai protes dari orang Bugis, mengingat tanah tersebut pada awalnya dimiliki oleh orang Bugis secara gratis dan dibeli dengan harga yang bagi mereka dapat dikatakan sudah dapat menuai keuntungan, informan penelitian ini juga menyebutkan bahwa mereka mengganggap pada dasarnya lahan tersebut diberikan oleh pemerintah dan kembali di beli oleh pemerintah, walaupun secara jelas mereka tidak mengetahui apakah lahan tersebut dibeli oleh pemerintah langsung, atau oknum pemerintahan atas nama pribadi. Etnis bugis pada dasarnya memang menyukai jual beli lahan. Mereka cenderung menjual lahan mereka dengan harga yang lebih tinggi saat mereka membelinya, kemudian pindah ke daerah pinggiran dan membeli lahan atau tanah yang lebih luas dibandingkan sebelumnya dengan harga yang lebih murah.

Lahan yang telah dimiliki oleh para pejabat biasanya dibiarkan hingga terealisasinya rencana pembangunan di daerah setempat. Saat daerah tersebut ditetapkan sebagai daerah yang dipersiapkan untuk dibangun perumahan maupun sarana penunjang lainnya, tentunya pemerintah mengundang para pengusaha swasta untuk bekerja sama. Para pengusaha swasta inilah yang pada akhirnya membeli kembali lahan tersebut dari para pejabat. Hal ini dianggap aman karena walaupun tanah tersebut memiliki potensi konflik atau bermasalah, ada anggapan bahwa selama membeli dari para pejabat, mereka akan tetap aman.

Berdasarkan pemaparan tersebut terlihat bahwa pada awalnya memang etnis Bugis sebagai penggarap adalah pemilik awal dari lahan-lahan di Balikpapan. Namun masuknya pendatang maupun pejabat atau elit politik yang biasa didatangkan dari pusat ke Balikpapan yang melirik lahan tersebut membeli lahan tersebut dengan harga yang murah. Orang Bugis yang lebih memilih berinvestasi tanah menerima harga tersebut kemudian pindah kepinggiran kota dan membeli lahan yang lebih luas dengan harga yang lebih murah dibandingkan harga tanah ditempat sebelumnya. Informan peneliti menambahkan bahwa hanya mereka yang dapat mengakses rencana tata kota lah yang dapat mengetahui bahwa harga tanah dibeberapa tempat akan meningkat dibandingkan sebelumnya. Para pejabat atau elit politik inilah yang akhirnya menjual dengan harga tinggi kepada pengusaha-pengusaha besar untuk membangun perumahan maupun sarana penunjang lainnya. Hal ini juga menjelaskan mengapa etnis Jawa di Balikpapan merupakan etnis yang juga suka berinvestasi diperusahaan-perusahaan tertentu atau menjadi pengusaha maupun membuka usaha kuliner. Pola penguasaan lahan dan peran paguyuban didalamnya lebih jelas terlihat dari tabel dibawah ini.

Tabel 3. Pola Penguasaan Lahan dan Peran Paguyuban di Balikpapan

\begin{tabular}{|c|c|c|c|}
\hline & Periode Awal & $\begin{array}{l}\text { Perubahan Kepemi- } \\
\text { likan Lahan }\end{array}$ & Pengembang \\
\hline Proses & $\begin{array}{l}\text { Orang Bugis } \\
\text { dengan kegiatan } \\
\text { "merintis" mem- } \\
\text { buka lahan dan } \\
\text { mend a a t a an } \\
\text { sertifikasi lahan } \\
\text { secara berkelom- } \\
\text { pok. }\end{array}$ & $\begin{array}{l}\text { Pejabat Jawa yang } \\
\text { dapat mengakses pe- } \\
\text { rencanaan pemban- } \\
\text { gunan dan tata kota } \\
\text { Balikpapan memiliki } \\
\text { sumber informasi ter- } \\
\text { kait lahan-lahan yang } \\
\text { akan memiliki nilai } \\
\text { jual tinggi, mereka } \\
\text { kemudian membeli } \\
\text { lahan-lahan tersebut } \\
\text { dari orang Bugis un- } \\
\text { tuk dijadikan investa- } \\
\text { si dan dijual kepada } \\
\text { pengembang. }\end{array}$ & $\begin{array}{l}\text { Lahan di- } \\
\text { jual kepada } \\
\text { pengembang } \\
\text { yang didomi- } \\
\text { nasi oleh etnis } \\
\text { Tionghoa se- } \\
\text { bagai pemilik } \\
\text { modal untuk } \\
\text { dikem ang- } \\
\text { kan sesuai } \\
\text { dengan ren- } \\
\text { cana tata kota } \\
\text { Balikpapan }\end{array}$ \\
\hline $\begin{array}{l}\mathrm{P} \text { e r a } n \\
\mathrm{P} \text { a } \\
\text { guyuban }\end{array}$ & $\begin{array}{l}\text { Menjadi tem- } \\
\text { pat sosialisasi } \\
\text { informasi dan } \\
\text { pengembangan } \\
\text { jejaring. Ser- } \\
\text { ta memberikan } \\
\text { bantuan dan } \\
\text { fasilitas bagi et- } \\
\text { nis Bugis baik } \\
\text { dalam melaku- } \\
\text { kan kan miatan } \\
\text { "merintis" mau- } \\
\text { pun sertifikasi } \\
\text { lahan }\end{array}$ & $\begin{array}{l}\text { Menjadi tempat so- } \\
\text { sialisasi informasi } \\
\text { dan pengembangan } \\
\text { jejaring untuk dapat } \\
\text { mengakses kepemi- } \\
\text { likan lahan-lahan } \\
\text { strategis dan menjual } \\
\text { kepada pengembang }\end{array}$ & $\begin{array}{l}\text { Menjadi tem- } \\
\text { pat sosialisa- } \\
\text { si informas } \\
\text { dan pengem- } \\
\text { bangan je- } \\
\text { jaring dalam } \\
\text { meng a s es } \\
\text { informasi ter- } \\
\text { kait proyek- } \\
\text { proyek pem- } \\
\text { bangunan }\end{array}$ \\
\hline
\end{tabular}

Paguyuban sebagai wadah berkumpul dan sosialisasi nilainilai pada umumnya menjadi sarana tolong-menolong dan saling bertukar informasi. Dimana melalui paguyuban sebagai representasi dari pilarisasi masyarakat masingmasing elit yang memiliki kekuasaan dalam mengakses sumberdaya ekonomi saling menginformasikan dan menolong sesama etnis dengan tujuan peningkatan ekonomi maupun kesejahteraan mereka. Pada kasus kepemilikan lahan, terlihat bahwa secara terpola kepemilikan lahan di Karang Joang berpindah dari etnis Bugis kemudian dimiliki oleh etnis Jawa dan terakhir dikuasai oleh etnis Tionghoa maupun pengusaha. Pola-pola hubungan ini sesungguhnya semakin melembaga dengan adanya peran paguyuban didalamnya. 
Peran paguyuban berdasarkan etnik dalam pemanfaatan prose pembangunan infrastruktur desa

Pembangunan kawasan desa selain tergantung pada penguasaan lahan juga tergantung pada penguasa setempat dan pembangunan yang terjadi di Desa setempat. Jika kembali terhadap pemaparan dari McGee (2009) yaitu bahwa zona desa-kota adalah di mana sebagian besar dari kegiatan didaerah tersebut adalah perkotaan dan didominasi oleh bangunan perkotaan. Wilayah ini mungkin sebelumnya telah ditandai dengan pertanian dan fase awal industrialisasi padat karya namun kegiatan tersebut sekarang telah banyak diganti dengan kegiatan perkotaan yang berhubungan erat dengan inti kota. Mengacu pada pendapat McGee, Karang Joang menurut data podes (2011) menyebutkan bahwa sumber penghasilan utama penduduknya didominasi oleh masyarakat yang memiliki mata pencaharian di bidang pertanian. Hal ini sesuai dengan kondisi di Karang Joang bahwa pekerjaan penduduk miskin di Karang Joang didominasi oleh petani gurem, buruh, dan serabutan.

Dewasa ini cukup banyak pembangunan yang masuk ke Karang Joang dimana pembangunan tersebut dibangun untuk melengkapi keperluan masyarakat kota. Sebagai contoh di Karang Joang terdapat satu-satunya politeknik negeri di Balikpapan, yaitu Politeknik Balikpapan, namun tidak banyak dari masyarakat Karang Joang yang termasuk lulusan dari politeknik tersebut. Bahkan dari semua responden penelitian ini hampir tidak ada yang memiliki anggota keluarga yang pernah kuliah maupun termasuk lulusan politeknik Balikpapan. Selain itu rencananya pada tahun 2014 akan dibuka Institut Tekhnologi Kalimantan (ITK) di Karang Joang.

Tidak hanya institusi pendidikan saja yang dibangun di Karang Joang. Selain institusi pendidikan, dibangun pula Karang Joang Golf and Resort. pembangunan sarana olahraga dan wisata ini tentunya bukan diperuntukkan bagi penduduk disekitar Karang Joang, melainkan untuk penduduk kota maupun para turis atau warga negara asing yang berkunjung ke Balikpapan. Baik karena urusan pekerjaan maupun wisata. Adapun institusi pendidikan dan sarana wisata daerah Karang Joang antara lain dapat dilihat lebih jelas pada gambar 3 .

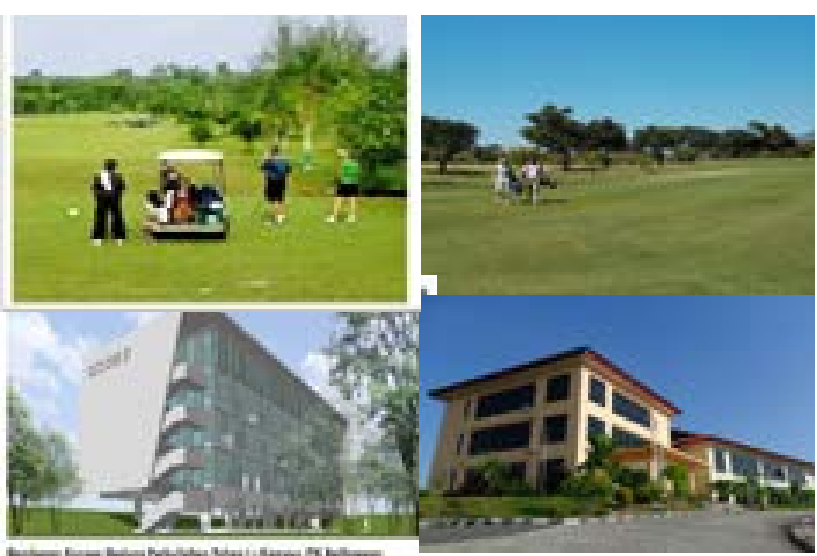

Gambar 3 Karang Joang Golf and Resort (atas), Institut Tekhnologi Balikpapan (kiri bawah), dan Politeknik Balikpapan (kanan bawah)

Pada gambar diatas terlihat pembangunan yang terjadi di daerah Karang Joang, namun pembangunan tersebut sangat jauh berbeda dengan kondisi pemukiman warga Karang Joang. Hal ini dapat lebih jelasnya dapat terlihat pada gambar 4
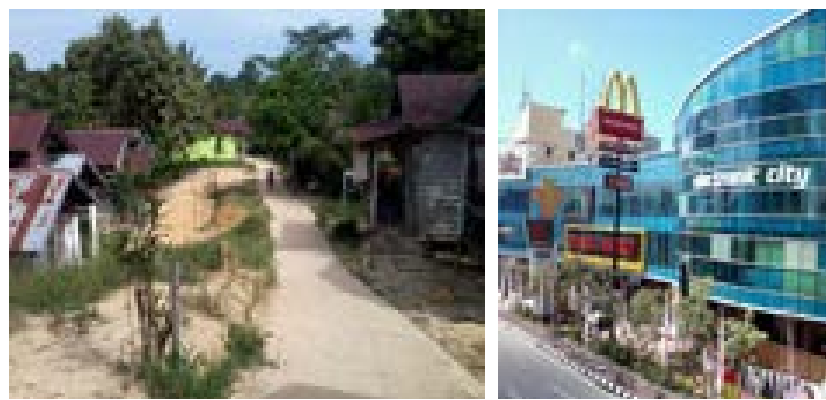

Gambar 4 Kondisi Pemukiman Warga Karang Joang (Kiri) dan Kondisi Balikpapan Kota (Kanan)

Merujuk pada gambar terlihat bahwa terdapat perbedaan yang cukup jauh antara Balikpapan kota dan rumah pemukiman warga di Karang Joang. Tentunya menarik untuk melihat bagaimana pembangunan kawasan yang megah ternyata tidak berbanding lurus dengan pembangunan pemukiman warga di Karang Joang. Terkait untuk memahami hal tersebut maka penting untuk melihat pemimpin yang menjabat untuk melihat arah pengembangan kebijakan yang dilakukan, adapun sejarah Walikota Balikpapan. Hal ini dapat lebih jelasnya terlihat pada tabel 4.

Tabel 4 Nama Walikota Balikpapan Sejak Tahun 1960 Hingga Sekarang

\begin{tabular}{|c|c|c|}
\hline No & Nama Walikota & Tahun \\
\hline 1 & H.A.R.S.MUHAMMAD & $1960-1963$ \\
\hline 2 & $\begin{array}{l}\text { MAYOR TNI. AD BAMBANG } \\
\text { SOETIKNO }\end{array}$ & $1963-1965$ \\
\hline 3 & MAYOR TNI.AD IMAT SAILI & $1965-1967$ \\
\hline 4 & MAYOR POL.ZAINAL ARIFIN & $1967-1973$ \\
\hline 5 & $\begin{array}{l}\text { LETKOL.POL.H.M.ASNAWI AR- } \\
\text { BAIN }\end{array}$ & $1974-1981$ \\
\hline 6 & $\begin{array}{l}\text { KOL.CZI.TNI.AD.SYARIFUDIN } \\
\text { YOES }\end{array}$ & $1981-1989$ \\
\hline 7 & $\begin{array}{l}\text { H. HERMAIN OKOL (Sebagai Plt. } \\
\text { Walikota) }\end{array}$ & $1989-1991$ \\
\hline 8 & KOL.INF.H.TJUTJUP SUPARNA & 1991 - Juni 2001 \\
\hline 9 & H. IMDAAD HAMID & Juni 2001 - 2011 \\
\hline 10 & H. M. RIZAL EFFENDI & $\begin{array}{l}2011 \text { - s.d.Seka- } \\
\text { rang }\end{array}$ \\
\hline
\end{tabular}

Sumber: Website Resmi Kota Balikpapan

Merujuk pada tabel, saat Balikpapan resmi berpisah dengan kesultanan Kutai dan menjadi kotamadya maka terjadi serah terima pemerintahan dari Kepala Daerah Istimewa Kutai yaitu Sultan Aji Muhammad Parikesit kepada Bupati Kutai, Walikota Samarinda dan Walikota Balikpapan yang pertama yaitu adalah H. Aji Raden Sayid Muhammad. Terpilihnya beliau tentunya tidak terlepas dari status beliau sebagai bangsawan tinggi Kutai yang 
memiliki gelar setingkat dibawah Aji Pangeran dan Aji Putri yang merupakan keturunan dari Sultan. Adapun selanjutnya saat orde baru, selama pemerintahan orde baru Walikota Balikpapan didominasi oleh militer yang lebih dominan beretnis Jawa. Hal ini ditunjukkan dari sepuluh walikota yang pernah menjabat di Kota Balikpapan tujuh diantaranya berasal dari militer. Rezim militer ini baru runtuh sejak berakhirnya orde baru dengan terpilihnya $\mathrm{H}$. Imdaad Hamid yang kemudian diikuti dengan terpilihnya H.M. Rizal Effendi sebagai Walikota Balikpapan yang merupakan etnis banjar.

Jika melihat tiga pembangunan yang paling menonjol di Desa Karang Joang yaitu Golf \& Resort Karang Joang Balikpapan dan Politeknik Balikpapan serta Institut Tekhnologi Kalimantan (ITK) tidak bisa terlepas dari kaitannya dengan pejabat setempat. Karang Joang Golf \& Resort di bangun pada saat dibawah kepemimpinan Walikota Kol.Inf.H.Tjutjup Suparna. Pada awalnya sebelum dibangun menjadi lapangan golf, kawasan ini merupakan kawasan $\mathrm{HPH}$ salah satu perusahaan kayu milik etnis Tionghoa di Balikpapan. Namun seiring berjalannya waktu bisnis kayu tidak lagi menjadi bisnis yang menguntungkan, maka pemilik perusahaan ini merubah fungsi lahan menjadi lapangan golf mengingat Balikpapan kini mulai menjadi kota industri dengan banyak penanaman modal asing di dalamnya. Sehingga lapangan golf ini pada dasarnya diperuntukkan untuk para pengusaha maupun pendatang khususnya dari luar negeri. Pada masa ini tidak terlalu jelas bagaimana mekanisme perizininan perubahan fungsi lahan tersebut terjadi. Pada pemerintahan Kol.Inf.H.Tjutjup Suparna, fokus pengembangan Balikpapan lebih kepada pengembangan jasa, dimana hal ini ditujukan kepada para pendatang yang didominasi oleh warga Negara asing yang berinvestasi di Balikpapan, sehingga arah pembangunan kebijakan lebih kepada untuk memfasilitasi kenyamanan di Balikpapan sebagai kota jasa.

Baru pada tahun 2000 Balikpapan yang tadinya lebih banyak membangun infrastruktur kebutuhan industri dan jasa bagi para pendatang, pada tahun 2000 digagas pembentukan politeknik Balikpapan. Hal ini juga yang gunakan oleh $\mathrm{H}$. Imdaad Hamid, SE bersama Mukmin Faisyal selaku Calon Walikota dan Calon Wakil Walikota pada Pemilukada tahun 2001 dalam penyampaian Visi dan Misinya, menyatakan akan Menjadikan Warga Balikpapan Menjadi Tuan di Rumah Sendiri. Dengan kata lain Balikpapan ingin agar putra-putri Balikapapan memiliki kemampuan yang memadai untuk dapat bekerja pada perusahaan-perusahaan besar/multi nasional yang ada di Balikpapan khususnya dan Kalimantan Timur pada umumnya. Pada kasus ini, etnis Banjar merupakan etnis yang tidak memiliki kebiasaan merantau yang tinggi, hal ini seperti yang dijelaskan oleh LKH

\section{"Orang Banjar kecenderungannya tidak merantau, mereka hidup berkebun dan bertani. Nelayan juga ada, tetapi berbeda dengan orang Bugis yang bisa merantau kedaerah lain"”}

Sebagai etnis yang cenderung tidak merantau maka membangun kelengkapan fasilitas di daerah menjadi penting untuk meningkatkan kapasitas sumberdaya manusia etnis Banjar. Paguyuban sebagai tempat penguatan identitas budaya yang melanggengkan nilai budaya serta jaringan kekuatan politik dalam kaitannya dengan dukungan politik kepada elit dan kepentingan bagi peningkatan kapasitas anggotanya tentunya memperkuat fenomena ini.

Selanjutnya kemudian digagas pembangunan Institut Tekhnologi Kalimantan (ITK) di Karang Joang yang mulai dibangun pada tahun 2012. Pembangunan ini direncanakan akan membebaskan sebanyak 300 hektar untuk pembangun Institut Tekhnologi Kalimantan (ITK). Tentunya menjadi pertanyaan besar siapa saja pemilik lahan yang nantinya akan dibebaskan dan dibangun ITK diatasnya. Terkait hal ini ketua DPRD Kota Balikpapan Andi Burhanudin Solong (ABS) dalam Koran Manuntung menuding banyak pejabat di lingkungan Pemkot menguasai lahan-lahan strategis yang digunakan untuk pembangunan. Hal itu ditenggarai memicu hingga belum tuntasnya sejumlah pembebasan lahan. Hal ini seperti yang ditegaskan oleh ABS dalam Koran Manuntung

"Saya tahu banyak pejabat Balikpapan yang punya tanah-tanah, saya tahu siapa-siapa mereka,"

Masih dalam Koran Manuntung ABS mengaku banyak menerima laporan dari masyarakat, terkait banyak pejabat yang memiliki lahan hingga berhektar-hektar. Hanya saja, tanah-tanah tersebut, justru diatasnamakan orang lain, bukan pejabat itu sendiri. Disebutkannya, beberapa lahan strategis yang dikuasi sejumlah pejabat di antaranya lahan untuk pembangunan stadion dan Institut Teknologi Kalimantan (ITK). Adapun terkait hal ini Kepala Bappeda Balikpapan Suryanto, mengakui, dirinya dan beberapa pejabat lainnya memang memiliki lahan sekitar 1,5 hektar di kawasan yang akan dibangun ITK tersebut. Paguyuban sebagai tempat sosialisasi informasi dan jaringan juga berperan dalam hal ini, dimana ABS yang merupakan etnis Bugis dapat mengakses informasi-informasi mengenai kepemilikan lahan-lahan strategis, mengingat pada awalnya lahan-lahan tersebut pada umumnya dimiliki oleh etnis Bugis

Berdasarkan pemaparan tersebut, terdapat kaitan antara pola penguasaan lahan yang telah dibahas sebelumnya. Dimana pada dasarnya baik kepemilikan lahan dan pembangunan kawasan erat kaitannya dengan etnis yang menguasai lahan. Lahan-lahan yang telah tersertifikasi dibeli oleh pejabat politik yang dominan etnis Jawa yang kemudian dijual kepada para pengusaha Tionghoa. Hal ini pun tidak lepas dari peran paguyuban sebagai wadah saling berkumpul dan pengembangan jaringan dari aktor politik kepada anggotanya. Peran paguyuban dan kepentingan etnisitas dalam pemanfaatan proses pembangunan infrastruktur desa dapat lebih jelasnya dilihat pada tabel berikut.

Paguyuban pada dasarnya berperan dalam pembangunan kawasan desa dengan sosialisasi nilai-nilai yang dilakukan secara turun temurun kepada anggotanya khususnya kepada para elit, dimana masing-masing elit saling mengutamakan kepentingan etnisnya. Terkait pembangunan di Karang Joang terlihat bahwa pembangunan tersebut pada dasarnya lebih bermanfaat untuk masyarakat dan kegiatan kota, adapun paguyuban mendukung pembangunan tersebut dilihat dari aktor-aktor yang berperan. Selain itu pembangunan institusi pendidikan diinisiasi oleh walikota H. Imdaad Hamid, SE, hal ini seperti yang telah dipaparkan sebelumnya adalah agar putra-putri Balikpapan memiliki kompetensi yang sesuai untuk bekerja di perusahaan, hal ini juga erat dengan etnis Banjar sebagai masyarakat yang tidak memiliki kebiasaan merantau yang tinggi, sehingga 
banyak penyediaan sarana penunjang harus dilengkapi didaerah asal, begitu pula dengan kebutuhan penyedian pendidikan pada dasarnya juga dapat dipergunakan untuk memperkuat bargaining etnis Banjar di Balikpapan, dimana etnis Banjar terkadang secara tidak disadari mulai melekat dan hampir menjadi representasi dari penduduk asli Balikpapan. Selain itu etnis Jawa juga memiliki kepentingan dalam pembangunan ini melihat lahan pembangunan pada awalnya didominasi oleh mereka, seperti yang telah dipaparkan sebelumnya. Walaupun secara tidak langsung peran paguyuban jelas mendukung pembangunan desa untuk eksistensi masyarakat dan pilarnya.

\section{Tabel 5 Peran Paguyuban dan Kepentingan Etnisitas dalam Pemanfaatan Proses Pembangunan Infrastruktur Desa Karang Joang di Balikpapan}

\begin{tabular}{|c|c|c|c|}
\hline & Etnis Jawa & Etnis Bugis & Etnis Banjar \\
\hline Proses & $\begin{array}{l}\text { Pembangunan } \\
\text { sarana dalam } \\
\text { bidang jasa dan } \\
\text { kepemilikan } \\
\text { lahan-lahan } \\
\text { strategis }\end{array}$ & $\begin{array}{l}\text { Pengawas dan } \\
\text { kontrol akan } \\
\text { pembangunan } \\
\text { sarana pub- } \\
\text { lik sebagai } \\
\text { sarana untuk } \\
\text { menunjang } \\
\text { kewajiban } \\
\text { sebagai elit } \\
\text { politik }\end{array}$ & $\begin{array}{l}\text { Pemenuhan ke- } \\
\text { butuhan etnis } \\
\text { Banjar dalam } \\
\text { peningkatan } \\
\text { kapasitas sum- } \\
\text { berdaya manu- } \\
\text { sia dan sebagai } \\
\text { janji politik }\end{array}$ \\
\hline $\begin{array}{l}\text { Peran Pa- } \\
\text { guyuban }\end{array}$ & $\begin{array}{l}\text { Menjadi tem- } \\
\text { pat sosialisasi, } \\
\text { kebutuhan ang- } \\
\text { gota, informasi } \\
\text { dan pengem- } \\
\text { bangan jejaring } \\
\text { untuk dapat } \\
\text { mengakses } \\
\text { kepemilikan } \\
\text { lahan-lahan } \\
\text { strategis. }\end{array}$ & $\begin{array}{l}\text { Menjadi tem- } \\
\text { pat sosialisa- } \\
\text { si informasi } \\
\text { dan jaringan } \\
\text { untuk dapat } \\
\text { mengetahui } \\
\text { kepemilikan } \\
\text { lahan-lahan } \\
\text { strategis }\end{array}$ & $\begin{array}{l}\text { Menjadi tem- } \\
\text { pat sosialisa- } \\
\text { si informasi, } \\
\text { k a m p a n y e } \\
\text { politik, dan } \\
\text { pengembangan } \\
\text { jaringan untuk } \\
\text { dukungan poli- } \\
\text { tik dan kepent- } \\
\text { ingan anggota }\end{array}$ \\
\hline
\end{tabular}

Peran paguyuban dalam bentuk pilarisasi masyarakat menuju demokrasi konsosiasional

erkait yang telah dipaparkan sebelumnya dimana masingmasing etnis mempunyai kepentingan tersendiri dalam sejarah pembangunan tentunya hal ini juga dapat memicu konflik. Adapun konflik yang pernah terjadi adalah antara paguyuban GEPAK (Kalimantan Timur) dan Lagaligo (Bugis). Namun, konflik ini akhirnya diselesaikan secara musyawarah oleh Forum Komunikasi Paguyuban Balikpapan (FKPB) yang memiliki kontrol sosial yang tinggi terhadap masyarakat. Hal ini secara tidak langsung menunjukkan pola pilarisasi masyarakat. Masyarakat tersegmentasi berdasarkan etnik namun tidak ada hirarki diantara kelompok ini. Hal ini menegaskan bahwa pola pilarisasi masyarakat etnis di Balikpapan yang mendorong munculnya demokrasi konsosiasional. Selanjutnya sebagaimana dikemukakan oleh Van Den Berghe (1981) dalam Sanderson (1993), konsosiasional adalah suatu situasi yang sangat rapuh, dan beberapa faktor penting harus bekerja bersama untuk membuatnya berjalan. Ditandaskannya bahwa demokrasi konsosiasional sangat cenderung berhasil bilamana berbagai kelompok etnik itu saling merembes secara territorial, genetik, dan fungsional, yakni apabila kelompok-kelompok etnik itu tercampur secara geografis yang ekstensif; apabila terdapat tingkat saling kawin-mawin yang tinggi diantara kelompokkelompok itu; dan apabila mereka memiliki lembagalembaga ekonomi, keagamaan, linguistik, dan kebudayaan yang sama. Ciri ini juga ditemukan di Balikpapan, walaupun masih ada lokasi-lokasi yang memang didominasi oleh etnis tertentu tetapi tingkat kawin-mawin antar etnis di Balikpapan cukup tinggi. Sebagai contoh ketua DPRD yang memiliki etnis bugis menikah dengan wanita ber-etnis Jawa. Fenomena ini juga dijelaskan oleh salah satu kasubid kesos di salah satu kelurahan di Balikpapan menyebutkan

"Disini walaupun dominan bugis, tetapi sudah banyak yang menikah beda etnis. Hampir pegawai kelurahan sini semuanya menikah antar etnis,

Selain pernyataan diatas ZA juga menambahkan bahwa di paguyuban batak cukup banyak anggotanya yang menikah antar etnis. Selain itu bergabungnya semua paguyuban etnis dalam satu wadah yaitu Forum Komunikasi Paguyuban dengan legalitas yang diberikan bagi ketua paguyuban untuk mewakili etnisnya di Balikpapan serta adanya kesepakatan diantara mereka untuk menjaga kondisi Balikpapan dari konflik etnis membuat interaksi antar paguyuban lebih bersifat harmonis. Bergabungnya semua paguyuban etnis dalam satu wadah yaitu forum komunikasi paguyuban serta adanya kesepakatan diantara mereka untuk menjaga kondisi Balikpapan dari konflik etnis membuat interaksi antar paguyuban lebih bersifat harmonis.

\section{KESIMPULAN}

Paguyuban etnis di Balikpapan merupakan tempat sosialisasi dan melembaganya nilai-nilai yang secara turun temurun disosialisasikan dan mempengaruhi aktor atau individu dalam berprilaku. Fenomena ini secara tidak langsung semakin memperkuat identitas etnik dari masingmasing etnis di Balikpapan, dimana hal ini mendorong terbentuknya pilarisasi masyarakat di Balikpapan. Selain itu, paguyuban juga berperan dalam pembangunan kawasan Karang Joang dimana melalui sosialisasi dan pola-pola hubungan etnisitas dalam wujud pilarisasi melalui elitelitnya tentunya saling mengutamakan kepentingan etnisnya dalam hal pembangunan kawasan pedesaan.

\section{Saran}

Fenomena pilarisasi masyarakat di Balikpapan khususnya di pedesaan tentunya membawa dampak positif dan negatif pada masyarakat. Adapun penelitian mengenai fenomena ini di Balikpapan belum banyak dilakukan sehingga perlu adanya penelitian lanjutan terkait fenomena pilarisasi masyarakat khususnya terkait pengaruhnya terhadap kesejahteraan masyarakat dan reduksi konflik.

\section{DAFTAR PUSTAKA}

Esman, Milton J. 1994. Ethnic Politics. New York: Cornell University Press.

Lawang, Robert MZ. 2005. Kapital Sosial dalam Perspektif Sosiologik: Suatu Pengantar. Jakarta: Fisip UI Press.

Lubis, Zulkifli B. 2005. Kanalisasi ketegangan etnik dan kompetisi budaya dalam sektor. Jurnal Antropologi Sosial Budaya ETNOVISI. 1(1). 
Nadzir, Ibnu. 2011. Kasus multikulturalisme belanda sebagai kritik atas utopia multikulturalisme Indonesia. Jurnal Masyarakat Indonesia. 37(2).

Tribun Kaltim. 2012. FKPB Gelar Silaturahmi dan Halam Bihalal [Internet]. [2013 Juni 7]. Diunduh dari http://kaltim.tribunnews.com/2012/09/30/fkpbgelar-silaturahmi-dan-halal-bihalal 